\title{
Focal Osteoporotic Bone Marrow Defects on Dental Implant Treated Patients: A 5-Year Period Prevalence Study
}

\author{
Defectos Focales Osteoporóticos de la Médula Ósea en Pacientes Tratados \\ con Implantes Dentales: Estudio Prevalencia de Período a 5 Años
}

Miguel Simancas-Pallares*; Luisa Arévalo-Tovar* \& Mauro Marincola**

SIMANCAS-PALLARES, M.; ARÉVALO-TOVAR, L. \& MARINCOLA, M. Focal osteoporotic bone marrow defects on dental implant treated patients: a 5-year period prevalence study. Int. J. Odontostomat., 10(1):23-28, 2016.

\begin{abstract}
Dental implants are considered the most effective treatment for teeth absence. Nevertheless, there are some bone conditions that could affect the osseointegration process, thus affecting the clinical and radiographic success rates. One of these conditions could be the Focal Osteoporotic Bone Marrow Defects. The objective of this study was to describe the 5-year period prevalence of Focal Osteoporotic Bone Marrow Defects (FOBMD) on dental implant treated patients. descriptive retrospective study was conducted. We systematically reviewed the clinical and radiographic data of treated patients in a Dental Implant Unit since January 2010 through December 2014. Once a FOBMD case was found, a detailed questionnaire was applied to the chart looking for demographic, medical and dental characteristics (clinical and radiographic). Also in a sub-sample histological analysis was carried out. Period prevalence (PP) was estimated calculating proportions and $95 \%$ confidence intervals. Statistical analysis was performed using Stata v. 13.2 for Windows (Stata Corp., TX., USA). FOBMD 5-yPP was $9.52 \%$ (Cl $95 \%$ : 6.87-13.5 \%). We found 42 defects in 34 patients. Within the FOBMD patients, average age was $55.4 \pm 11.9$ years, $67.64 \%$ being females. Ninety-seven percent of the defects were located in the lower jaw, $79.41 \%$ unilateral, $69.04 \%$ single missed teeth lesions, $71.42 \%$ affecting molar area and $59.52 \%$ located on the right side of the maxillae. Histological analysis revealed inflammatory cells, dystrophic calcifications, hemorrhagic material and fatty cells for all the cases. FOBMD prevalence is low, so it should be considered as a rare condition but showing an exponential growing trend over the time. With no previous epidemiological data, these findings should be considered as a caution during x-ray examinations and treatment planning, in order to avoid surgical or prosthetic complications. Local factors as previous root canal treatments should be considered when elucidating reasons for its appearance.
\end{abstract}

KEY WORDS: dental implants, osseointegration, bone marrow diseases, oral surgical procedures.

\section{INTRODUCTION}

A Focal Osteoporotic Bone Marrow Defect (FOBMD) constitutes a radiolucent area in the bone that is consistent with hematopoietic tissue presence (Schneider et al., 1988; Shankland \& Bouquot, 2004). Usually it is asymptomatic, unless some nerves are involved, and accidentally discovered during presurgical radiographic analysis or even during the surgical steps.

FOBMD's are most commonly located in the molar area of middle-aged women (Barker et al., 1974). Its etiology still remains unknown but some evidence shows that they can be associated with a variety of inflammatory and non-inflammatory conditions (Eriksen \& Ringe, 2012). In a radiographic wise, it is a localized radiolucid area with different sizes, shapes, trabeculae and border definitions (Shankland \& Bouquot; Lipani et al., 1982). They are not be visible on plain X-rays and in some cases, neither on computed tomography (CT) (Eriksen \& Ringe).

Since dental implants represent the most effective treatment for tooth loss (Esposito et al., 2007), caution should be taken when analyzing pre-operatively

\footnotetext{
DDS. M.Sc. Professor. Research Department, Dental Implant Unit, Faculty of Dentistry, University of Cartagena, Cartagena, Colombia. * DDS. Periodontist. Professor. Oral Medicine and Surgery Department, Dental Implant Unit, Faculty of Dentistry. University of Cartagena, Cartagena, Colombia.

${ }^{* * *}$ DDS. MSD. Visiting Professor. Dental Implant Unit, Faculty of Dentistry, University of Cartagena, Cartagena, Colombia.
} 
the radiographic images with this type of defects in order to achieve adequate rates of clinical success (BravoCalderon et al., 2012). If FOBMD's are not detected, a displacement of the implant can occur intraoperatively or within a short period of time due to lack of bone for primary stability (Lee et al., 2013). This complication can lead to clinical challenges as difficult uncovering of the implant and also the selection of long-post abutments or even the impossibility to restore it (Sencimen et al., 2011).

Due to that FOBMD's are occasionally not included in the differential diagnosis of other radiolucent lesions, knowledge of its radiographic, clinical and histopathological features in association with accurate clinical examination are necessary to distinguish them from other intrabony lesions (Bravo-Calderon et al.).

As previously shown, there is some evidence in the literature showing case reports about FOBMD's (Shankland et al.; Lipani et al.); nevertheless there are no studies showing concise epidemiological aspects of the disease in Latin America. Having this in mind, and given the clinical relevance of the disease, the main objective of our study was to describe the Focal Osteoporotic Bone Marrow Defects 5-year period prevalence (5y-PP-FOBMD) in dental implant treated patients.

\section{MATERIAL AND METHOD}

A descriptive retrospective study was conducted. For this, clinical charts of treated patients in a Dental Implant Unit between January 2010 and December 2014 were reviewed.

Once the clinical diagnosis was confirmed with the chart, patient was contacted looking for authorization by written informed consent of participation in this research. The same trained and experienced clinician as a consensus between anamnesis, radiographic and clinical findings, performed all the clinical diagnoses. Protocol was designed and carried out by following the Colombian ethical regulations (Decree Num. 8430, 1993) as well as the Helsinki statement for human beings protection during research conduction. The Ethics Institutional Review Board of the University of Cartagena approved this protocol.

Data was gathered through a pilot-tested specific questionnaire designed by the research team including socio demographic, clinical and radiographic parameters. In addition to this, results of histologic examination in a subset of the sample were recorded.

Harvested data was transferred into a Microsoft Excel ${ }^{\mathrm{TM}}$ spreadsheet containing all the clinical, radiographic and histological characteristics. Then calculating means \pm standard deviation for quantitative variables and proportions and $95 \%$ confidence intervals for qualitative data we performed analysis. Statistical analysis was carried out using Stata v.13.2 for Windows (Stata Corp., College Station, TX USA).

\section{RESULTS}

Socio demographic and general findings. Within the 5-year period, we found 357 dental implants treated patients with an average age of $50.6 \pm 13.3$ years and $66.7 \%$ being females. Thirty-four patients (patient-level sample unit) were diagnosed with the defects thus giving a $5 y-P P-F O B M D$ of $9.52 \%$. Among the FOBMD patients, average age was $55.4 \pm 11.9$ years old and $67.64 \%$ of patients were female. Socio demographic and general characteristics as well as the reasons for teeth extraction or its absence are listed in Table I.

Stratified by year, FOBMD prevalence was higher for 2013 and 2014 with $41.1 \%$ of the cases ( $n=$ 14); $17.85 \%$ for $2012(n=6)$ and $0 \%$ for 2011 and 2010 respectively.

Clinical findings. According to the jaw position, 97 $\%(n=33)$ of the patients showed FOBMD in the lower jaw and $79.41 \%(n=27)$ of the defects were unilateral. None of the patients showed simultaneous lesions on the upper/lower jaw. Since several patients had multiple defects/lesions, the final number of FOBMD was 42 (defect-level sample unit). $69.04 \%(n=29)$ were considered single-teeth lesions, $28.57 \%(n=12)$ affected up to two missing teeth and $2.38 \%(n=1)$ affecting three missing teeth. $71.42 \%(n=30)$ affected the molar, $16.7 \%(n=7)$ the premolar and $11.90 \%$ $(n=5)$ premolar and molar regions at the same time. Finally, $59.52 \%(n=25)$ and $40.47 \%(n=17)$ of the defects were located on the right and left side respectively.

Radiographic findings. Radiographic findings of FOBMD showed the same characteristics across the patients: radiolucent well-defined lesions with different sizes, shapes, trabeculae and border definitions (Fig. 1). 
Histological findings. Nineteen percent $(n=8)$ of the defect-level sample units were processed for histological examination. Regarding the histological features of the lesions, all of the cases showed consistent findings: inflammatory cells, dystrophic calcification, adipocytes and hemorrhagic material presence (Fig. 2).

Table I. Socio demographic characteristics and reasons for teeth extraction absence in the studied sample.

\begin{tabular}{lcc}
\hline Characteristic & Yes - \% (n) & No - \% (n) \\
\hline Medical Disease & $58.88(20)$ & $41.17(14)$ \\
Drug Intake & $70.58(24)$ & $29.41(10)$ \\
Smoking History & $5.88(2)$ & $94.11(32)$ \\
Alcohol Intake & $26.47(9)$ & $73.52(25)$ \\
\hline \multicolumn{2}{l}{ Teeth Extraction/Absence } & Reason - \% (n) \\
\hline Periodontal Disease & $7.14(3)$ \\
Failed RCT/Infection & $83.33(35)$ \\
Agenesis & $4.76(2)$ \\
Orthodontic Treatment & $4.76(2)$ \\
\hline
\end{tabular}

$\mathrm{RCT}=$ root canal treatment; \%= proportion; $\mathrm{n}=$ frequency.

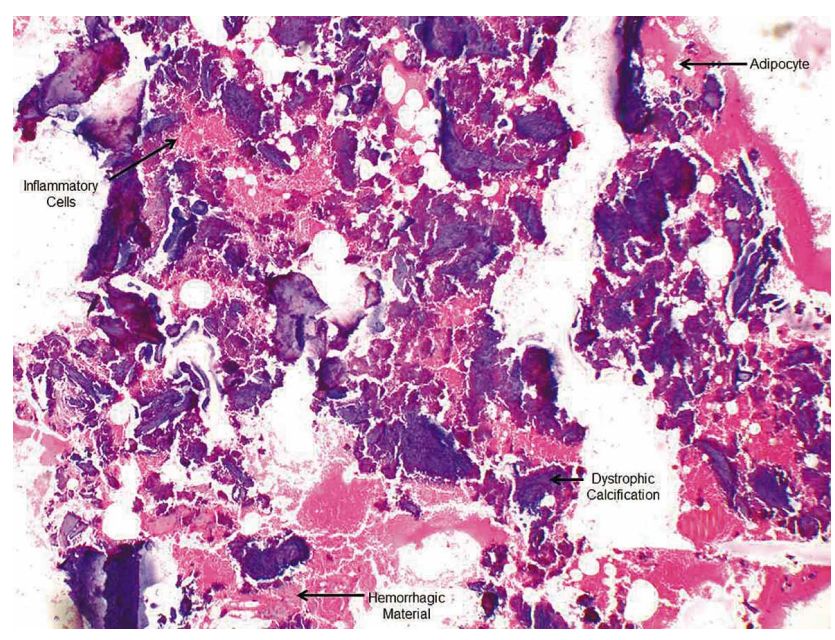

Fig. 2. Microscopic section at $4 \mathrm{X}$ of magnification in one of the samples. Black arrows indicate the histological findings.

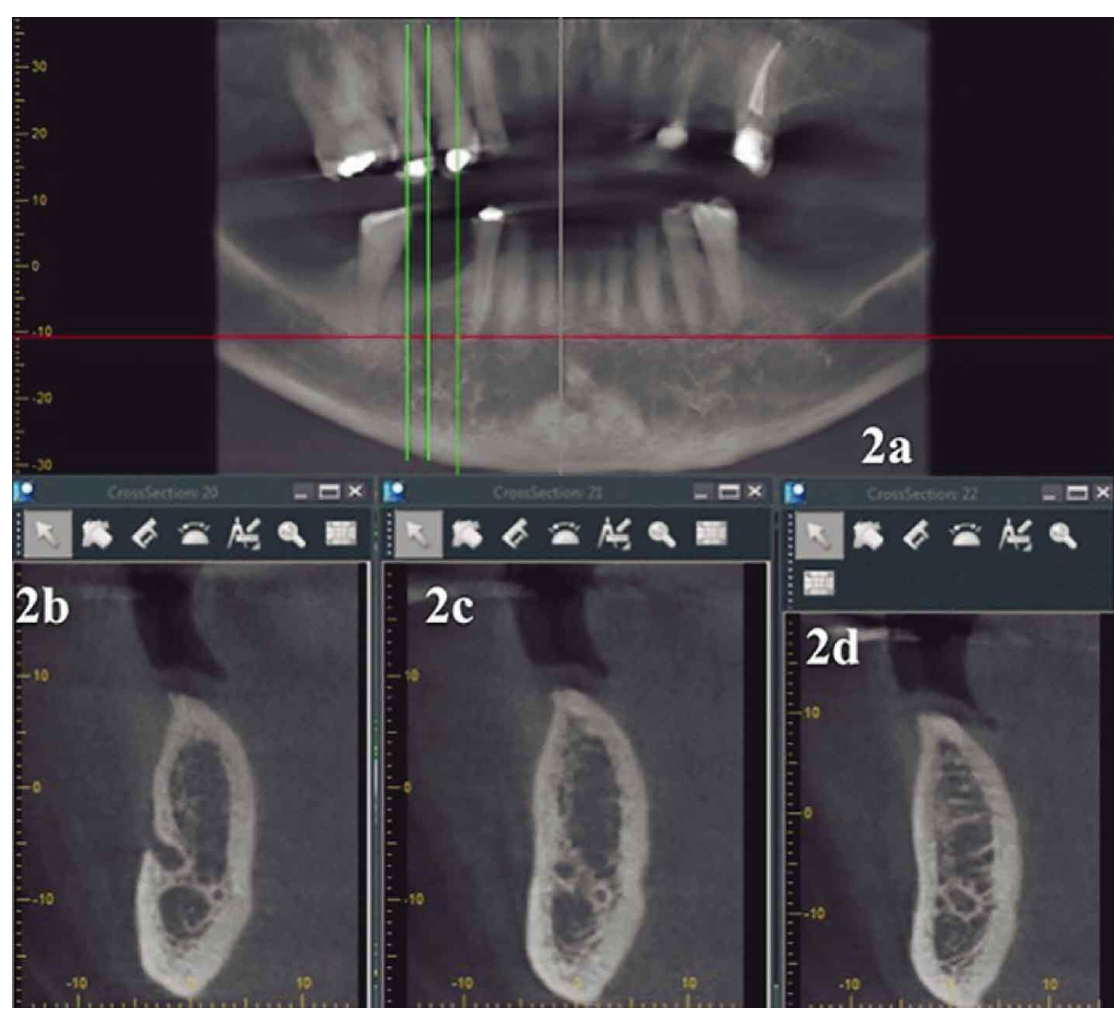

Fig. 1. Computerized tomography (CT) slide showing a well-defined lesion diagnosed as FOBMD in the lower right side of a female middle-aged patient. a) Shows in a panoramic level the presence of the radiolucid lesion. b) and c) Shows in a CT close-up the absence of a trabecular pattern inside the bone and a dense cortical at the crestal level of the ridge. d) Shows the adequate trabecular pattern of the bone.
FOBMD's has been reported as an unusual radiolucency often detected unexpectedly in the posterior mandible of the middle-aged patients and woman predominantly (Shankland et al.; Makek \& Lello, 1986; Bouquot \& Stevenson, 2006), which also is consistent with our results. According to the results of our study, more than a half of the affected patients were woman in the fourth to sixth decade of life. Other authors show that this condition can be associated with sickle cell anemia, rheumatoid arthritis and osteoporosis (Sanner \& Ramin, 1977; Eriksen \& Ringe) but these conditions were not present in the studied sample.

Its prevalence has not been widely informed since it is not a usual lesion/defect of the jaws, so clinical case reports have been noted in only two studies describing the clinical, radiographic and histological features of the condition in 197 and 100 new cases (Shankland \& Bouquot; Barker et al.) respectively. So far, this is the 
first study in Latin America describing its prevalence, clinical, radiographic and histological features.

According to the results of the present study and since an epidemiological point of view, the prevalence of the disease should be considered low; but even when the prevalence was low, this is the highest prevalence reported across the literature. Barker et al. described 197 cases on a 47.00015 -year study population thus giving a period prevalence of $0.42 \%$. Shankland \& Bouquot, reported 100 new cases but no prevalence could be determined since population size was not indicated.

Its etiology is not completely understood but some hypothesis have been proposed to explain it: aberrant bone regeneration after tooth extraction, persistence of fetal marrow and marrow hyperplasia in response to increased demand of erythrocytes (Barker et al.). Results of the present study showed that a large number of patients underwent root canal treatment (RCT); this could be a new hypothesis for FOBMD appearance. Employed biomaterials for endodontic irrigation such as sodium hypochlorite $(\mathrm{NaOCl})$ is reported to have deleterious effects on the bone structure. Some authors have reported localized interdental bone necrosis after RCT (Reddy et al., 2014). Kerbl et al. (2012) described in dogs the degradation of the organic matrix and grossly, caused significant changes in the bone cancellous structure, leaving it less dense and also large structural craters of apparent demineralization was found. Since FOBMD etiology is not fully understood and keeping in mind that in this study most patients had previous RCT on those sites, it is possible that $\mathrm{NaOCl}$ apical extrusion could explain the defect presence. Moreover, further studies are needed in order to confirm these hypotheses.

Another material commonly used for RCT performance is calcium hydroxide $(\mathrm{CaOH})$. Even though its beneficial properties in hard tissue healing has been widely described (Nagata et al., 2015; Moradi Majd et al., 2014), there is some evidence showing deleterious effects to adjacent tissues (Sharma et al., 2014). A case series illustrates the high toxicity of calcium hydroxide when displaced into blood vessels and soft tissues (Sharma et al., 2008). The $\mathrm{pH}$ of most $\mathrm{CaOH}$ pastes is approximately 12 . So, exposure to blood results in crystalline precipitation due to the intense difference in $\mathrm{pH}$ values. Theoretically, it cannot be considered a totally biocompatible material. Endodontic instrumentation may develop a form of communication to facilitate the passage of material into the blood vessel. The syringe technique is then able to generate pressures higher than the intra-arterial pressure in order to get retrograde flow along the artery. Therefore, it is hypothesized that the tissue damage must be due to material reaching the capillary bed and causing direct tissue toxicity and blood vessel blocks due to the precipitations (Sharma et al., 2008). Thus, the relatively poor vascularization available, leaves the bone marrow in the adult jaw vulnerable to trauma, bacterial invasion, vascular congestion, also with a drastic reduction of blood flow, potentially leading to a myriad of ischemic and inflammatory problems. So, local impairment of blood flow rates can support the etiology of FOBMD presence (Shankland \& Bouquot).

Bouquot \& Stevenson, reported bilateral occurrence of FOBMD's affecting $3 \%$ of the patients. Stated that there are many reports about this issue but the real incidence is not accurately established, probably due to the fact that most cases are asymptomatic and discovered in radiographic exam for diagnosis of oral condition or treatment planning. Some authors indicated that larger studies about this osteoporotic defect fail to mention the number of cases with available radiographs (Schneider et al.). Moreover, the results of our study show a higher prevalence of bilateral FOBMD's due to the fact of the rigorous method for radiographic assessment of the patients and X-Ray prescription as an initial step for treatment planning.

Since from a radiographic point of view, it is considered a well-defined radiolucency and also considering that those defects are seldom included in the differential diagnosis of radiolucent areas of the jaws; full knowledge of the pathological (clinical, radiographic and histological) is important in order to establish differential diagnosis from lesions including: ameloblastoma, keratocystic odontogenic tumor, developmental or inflammatory odontogenic cyst, and simple bone cyst (SBC); therefore an adequate treatment planning could be performed (Bravo-Calderon et al.; Chrysomali et al., 2013; Almeida et al., 2014).

Emphasis must be placed on further studies including analytical epidemiological designs in order to establish causal associations with some personal and dental factors like previous endodontic treatment. Additionally, the use of CBCT examination should not be discarded, as it constitutes one of the most accurate methods for hard-tissue assessment regarding dental implant treatments and several medical conditions (Kaya et al., 2012; Bagis et al., 2015; Jashari et al., 2015). 
SIMANCAS-PALLARES, M.; ARÉVALO-TOVAR, L. \& MARINCOLA, M. Defectos focales osteoporóticos de la médula ósea en pacientes tratados con implantes dentales: Estudio prevalencia de período a 5 años. Int. J. Odontostomat., 10(1):23-28, 2016.

RESUMEN: Los implantes dentales se consideran el tratamiento más eficaz para la ausencia dentaria. Sin embargo, hay algunas condiciones óseas que pueden afectar el proceso de osteointegración, lo que afecta a las tasas de éxito clínico y radiográfico. Una de estas condiciones podrían ser los defectos focales osteoporóticos de la médula ósea (DFOMO). El objetivo de este estudio fue describir la prevalencia en un periodo de 5 años de los DFOMO en pacientes tratados con implantes dentales. Se realizó un estudio descriptivo y retrospectivo, con una revisión sistemática de los datos clínicos y radiológicos de pacientes tratados en una unidad de implantes dentales desde enero de 2010 hasta diciembre de 2014. Cuando se encontró algún caso de DFOMO, se aplicó un cuestionario detallado sobre la ficha en busca de características demográficas, médicas y dentales (clínicas y radiográficas). También se realizó un análisis histológico de la submuestra. Se estimó la prevalencia del periodo (PP), el cálculo de proporciones e intervalos de confianza con un $95 \%$. El análisis estadístico se realizó con el programa Stata v. 13.2 para Windows (Stata Corp, TX., EE.UU.). La prevalencia del periodo para los 5 años de DFOMO fue 9,52 \% (IC del $95 \%$ : 6,87 \% a 13,5\%). Encontrado 42 defectos en 34 pacientes. Dentro de los pacientes con DFOMO, la edad promedio fue de $55,4 \pm 11,9$ años, y $67,64 \%$ fueron mujeres. El $97 \%$ de los defectos se encuentraran en la mandíbula. El 79,41 \% fue unilateral y $69,04 \%$ con lesiones individuales de pérdidas dentarias; el 71,42 $\%$ afectó la zona de los molares y 59,52 \% se encontró en el lado derecho del maxilar. El análisis histológico reveló células inflamatorias, calcificaciones distróficas, material hemorrágico y células grasas, en todos los casos. La prevalencia de DFOMO fue baja, por lo que debe considerarse como una enfermedad poco frecuente pero que muestra una tendencia creciente y exponencial en el tiempo. Sin datos epidemiológicos previos, estos resultados deben ser considerados para tener precaución durante los exámenes imagenológicos y la planificación del tratamiento, con el fin de evitar complicaciones quirúrgicas o prótesicas. Los factores locales como tratamientos endodónticos previos deben ser considerados para dilucidar las razones de su aparición.

PALABRAS CLAVE: implantes dentales, osteointegración, enfermedades de la médula ósea, procedimientos quirúrgicos orales.

\section{REFERENCES}

Almeida, L. Y.; Kato, R. B.; Ribeiro, M. C. \& León, J. E. Focal osteoporotic bone marrow defect mimicking a mandibular cystic lesion. J. Craniofac. Surg., 25(4):e324-6, 2014.

Bagis, N.; Kolsuz, M. E.; Kursun, S. \& Orhan, K. Comparison of intraoral radiography and cone-beam computed tomography for the detection of periodontal defects: an in vitro study. B. M. C. Oral Health, 15:64, 2015.

Barker, B. F.; Jensen, J. L. \& Howell, F. V. Focal osteoporotic bone marrow defects of the jaws. An analysis of 197 new cases. Oral Surg. Oral Med. Oral Pathol., 38(3):404-13, 1974.

Bouquot, J. E. \& Stevenson, G. Oral and maxillofacial pathology case of the month. Focal osteoporotic marrow defect (Hematopotic bone marrow defect; focal hematopoietic hyperplasia). Tex. Dent. J., 123(11):10612, 1066-8, 2006

Bravo-Calderon, D. M.; Oliveira, D. T. \& Dos Santos, W. H. M. Bilateral osteoporotic bone marrow defects of the mandible: a case report. Head Face Med., 8:22, 2012.

Chrysomali, E.; Leventis, M.; Titsinides, S.; Kyriakopoulos, V. \& Sklavounou, A. Odontogenic tumors. J. Craniofac. Surg., 24(5):1521-5, 2013.
Eriksen, E. F. \& Ringe, J. D. Bone marrow lesions: a universal bone response to injury? Rheumatol. Int., 32(3):575-84, 2012.

Esposito, M.; Grusovin, M. G.; Willings, M.; Coulthard, P. \& Worthington, H. V. The effectiveness of immediate, early, and conventional loading of dental implants: a Cochrane systematic review of randomized controlled clinical trials. Int. J. Oral Maxillofac. Implants, 22(6):893904, 2007.

Jashari, F.; Ibrahimi, P.; Johansson, E.; Ahlqvist, J.; Arnerlöv, C.; Garoff, M.; Jäghagen, E. L.; Wester, P. \& Henein, M. Y. Atherosclerotic Calcification Detection: A Comparative Study of Carotid Ultrasound and Cone Beam CT. Int. J. Mol. Sci., 16(8):19978-88, 2015.

Kaya, S.; Yavuz, I.; Uysal, I. \& Akkus, Z. Measuring bone density in healing periapical lesions by using cone beam computed tomography: a clinical investigation. J. Endod., 38(1):28-31, 2012.

Kerbl, F. M.; DeVilliers, P.; Litaker, M. \& Eleazer, P. D. Physical effects of sodium hypochlorite on bone: an ex vivo study. J. Endod., 38(3):357-9, 2012. 
Lee, S. C.; Jeong, C. H.; Im, H. Y.; Kim, S. Y.; Ryu, J. Y.; Yeom, H. Y. \& Kim, H. M. Displacement of dental implants into the focal osteoporotic bone marrow defect: a report of three cases. J. Korean Assoc. Oral Maxillofac. Surg., 39(2):94-9, 2013.

Lipani, C. S.; Natiella, J. R. \& Greene, G. W. Jr. The hematopoietic defect of the jaws: a report of sixteen cases. J. Oral Pathol., 11(6):411-6, 1982.

Makek, M. \& Lello, G. E. Focal osteoporotic bone marrow defects of the jaws. J. Oral Maxillofac. Surg., 44(4):26873, 1986.

Moradi Majd, N.; Zohrehei, H.; Darvish, A.; Homayouni, H. \& Adel, M. Continued root formation after delayed replantation of an avulsed immature permanent tooth. Case Rep. Dent.., 2014:832637, 2014.

Nagata, J. Y.; Rocha-Lima, T. F.; Gomes, B. P.; Ferraz, C. C.; Zaia, A. A.; Souza-Filho, F. J. \& De Jesus-Soares, A. Pulp revascularization for immature replanted teeth: a case report. Aust. Dent. J., 60(3):416-20, 2015.

Reddy, K. K.; Shankar, B. S.; Reddy, K. A.; Reddy, S. N.; Sudhakar, J. \& Reddy, P. S. Localizedinterdental bone necrosis: a case report. J. Int. Oral Health, 6(4):73-5, 2014.

Sanner, J. R. \& Ramin, J. E. Osteoporotic, hematopoietic mandibular marrow defect: an osseous manifestation of sickle cell anemia. J. Oral Surg., 35(12):986-8, 1977.

Schneider, L. C.; Mesa, M. L. \& Fraenkel, D. Osteoporotic bone marrow defect: radiographic features and pathogenic factors. Oral Surg. Oral Med. Oral Pathol., 65(1):127-9, 1988.

Sencimen, M.; Delilbasi, C.; Gulses, A.; Okcu, K. M.; Gunhan, O. \& Varol, A. Focal osteoporotic hematopoietic bone marrow defect formation around a dental implant: a case report. Int. J. Oral Maxillofac. Implants, 26(1):e1-4, 2011.

Shankland, W. E. \& Bouquot, J. E. Focal osteoporotic marrow defect: report of 100 new cases with ultrasonography scans. Cranio, 22(4):314-9, 2004.

Sharma, S.; Hackett, R.; Webb, R.; Macpherson, D. \& Wilson, A. Severe tissue necrosis following intra-arterial injection of endodontic calcium hydroxide: a case series. Oral Surg. Oral Med. Oral Pathol. Oral Radiol. Endod., 105(5):666-9, 2008.

Sharma, D. S.; Chauhan, S. P.; Kulkarni, V. K.; Bhusari, C. \& Verma, R. Accidental periapical extrusion of non-setting calcium hydroxide: unusual bone response and management. J. Indian Soc. Pedod. Prev. Dent., 32(1):63-7, 2014.
Correspondence to:

Miguel Simancas-Pallares

Zaragocilla. 30th St $18-152$

Health Sciences Campus

Research Department

Faculty of Dentistry

University of Cartagena

Room 301, Cartagena

COLOMBIA

Phone: +57 5 6698172. Line: 110 .

Email: msimancasp@unicartagena.edu.co

Received: 15-10-2015

Accepted: 03-02-2016 